Vol. VI-3, Desember 2010

\title{
KANDUNGAN VITAMIN C PADA OVARIUM IKAN LELE (Clarias gariepinus) SAAT SIKLUS REPRODUKSI
}

\author{
Hengky Sinjal \\ Staf Pengajar pada Program Studi Budidaya Perairan, \\ Fakultas Perikanan dan IImu Kelautan. UNSRAT. Manado 95115.
}

\begin{abstract}
Vitamin C content in the ovarium of African Catfish (Clarias gariepinus) during reproductive cycle was investigated. One hundred twenty samples of females covering different stages of reproductive cycle were collected from fresh water ponds. The fishes were sacrifized and the ovarium were collected for analysis of gonad maturation stage (TKG), oocyte structure and vitamin C content in the ovarium. Results indicated that average of vitamin $C$ content of ovarium at stage I was $74.33 \mu \mathrm{g} / \mathrm{g}$ (wet weight). The maximum content was found in stage III at level of $155.98 \mu \mathrm{g} / \mathrm{g}$ (wet weight) and afterwards in the next stage vitamin $C$ content decreased. The maximum of oocyt stadium 3 (oocyt vitelogenesis) was also found at this stage III. The findings indicate that vitamin $\mathrm{C}$ has a role in the reproductive cycle of catfish and its content is related to ovarium development and oogenesis.
\end{abstract}

Keywords: vitamin C content, reproductive, catfish (Clarias gariepinus).

\section{PENDAHULUAN}

Informasi kebutuhan gizi induk ikan untuk kepentingan produksi benih masih sangat terbatas dan berbagai penelitian umumnya masih ditekankan hanya pada kebutuhan protein dan lemak, dan ini telah terbukti bahwa kecukupan protein dan lemak selama berlangsungnya siklus reproduksi sangat mempengaruhi perkembangan ovarium dan mutu telur. Informasi kebutuhan nutrea lainnya seperti vitamin pada saat siklus reproduksi masin sangat terbatas. Lutwak-Mann (1958) telah mengawali pendapat adanya ketergantungan fungsi gonad atas vitamin. Dia mencatat adanya fluktuasi asam askorbat (vitamin C) pada ovarium kelompok mamalia, namun belum dimengerti peranannya dalam fisiologis-reproduksi.

Ikan lele (Clarias gariepinus) adalah spesies ikan air tawar yang sudah populer dibudidayakan, disukai oleh masyarakat, mudah dibudidayakan pada beberapa ekosistem, cepat pertumbuhannya dan mempunyai peluang sebagai komoditas ekspor. Ikan ini mudah berbiak sepanjang tahun, dengan periode pemijahan yang berfluktuasi. Informasi mengenai kebutuhan gizi spesifik vitamin untuk pakan induk ikan lele belum banyak diketahui, namun diduga bahwa kesediaan vitamin pada ovarium sangat berperanan dalam siklus reproduksi. Berdasarkan permasalahan di atas dilakukan pengamatan kandungan vitamin $\mathrm{C}$ pada ovarium ikan lele saat siklus reproduksi, sebagai informasi dasar kebutuhan dan peranan vitamin $\mathrm{C}$ dalam siklus reproduksi.

\section{BAHAN DAN METODE}

Contoh ikan lele yang digunakan dalam penelitian ini sebanyak 120 ekor yang diambil dari kolam pembesaran. Kisaran bobot ikan yang tertangkap adalah 389-638 gr. Ikan dimatikan dan ovarium diambil. Sebagian ovarium disimpan dalam botol berisi formalin buffer fosfat untuk digunakan dalam pengamatan struktur oosit (distribusi ukuran) oosit dan pembuatan preparat histologis. Kemudian sebagian contoh ovarium lainnya disimpan dalam kantong plastik, diisi dengan gas Nitrogen dan disimpan pada suhu $-30^{\circ} \mathrm{C}$ untuk analisis vitamin C. Preparat histologi disiapkan dengan mengikuti prosedur yang dikemukakan oleh Chinabut, et. al. (1991) dengan pewarnaan hematoksilin dan eosin. Preparat histologi dibuat untuk pengamatan diameter oosit pada setiap stadia perkembangan dan melihat spesifik tingkat kematangan gonad (TKG). Struktur oosit diamati 


\section{Kandungan Vitamin C pada Ovarium Ikan Lele}

dengan menggunakan mikroskop binokuler yang dilengkapi mikrometer. Struktur oosit diklasifikasikan menurut stadium oosit (stadium awal, previtelogenesis, vitelogenesis dan oosit matang) berdasarkan diameter oosit yang ditentukan dari pengamatan preparat histologis. Kandungan vitamin C ovarium dianalisis menurut metode pasangan ion (Schuep, et. al., 1994) dengan menggunakan HPLC (High Performance Liquid Chromatography) pada panjang gelombang $254 \mathrm{~nm}$ dan coloumn stainles steel $(25 \times 40 \mathrm{~mm})$ dijenuhi oleh C18 diameter 5 um (Shadon Southern Products, Atmoor, UK). Fase mobil yang digunakan adalah bufer asetat $\mathrm{pH} 4.8$ dan vitamin $\mathrm{C}$ terelusi setelah 6-8 menit. Contoh ovarium sebanyak $0,1 \mathrm{~g}$ diekstraksi dengan $5 \mathrm{ml}$ asam meta fosforik terdiri atas $0,2 \%$ ditiotreitol menggunakan penghancur jaringan (tissue homogenizer dengan kecepatan $1.500 \mathrm{rpm}$ selama 3 menit pada suhu $5^{\circ} \mathrm{C}$. Kemudian campuran diputar dengan kecepatan $4.000 \mathrm{rpm}$ selama 5 menit untuk memisahkan padatan dan larutan (filtrat). Filtrat disaring dengan menggunakan membran filter 0,45 um. Untuk mendapatkan informasi pola akumulasi kandungan vitamin $\mathrm{C}$ ovarium saat siklus reproduksi, data yang diperoleh disajikan dalam bentuk tabel frekuensi didasarkan pada tingkat kematangan gonad (TKG) contoh yang diamati.

Tabel 1. Distribusi kandungan vitamin $\mathrm{C}$ ovarium pada setiap Tingkat Kematangan Gonad (TKG)

\begin{tabular}{cccrrr}
\hline \multicolumn{6}{c}{ Tingkat kematangan gonad } \\
\hline $\begin{array}{c}\text { Vitamin C } \\
\text { content (uglg) }\end{array}$ & I & II & III & IV & V \\
\hline $60-80$ & 8 & 0 & 0 & 0 & 0 \\
$81-100$ & 4 & 0 & 0 & 2 & 2 \\
$101-120$ & 0 & 10 & 6 & 11 & 6 \\
$121-140$ & 0 & 12 & 8 & 15 & 3 \\
$141-160$ & 0 & 5 & 11 & 6 & 0 \\
$161-180$ & 0 & 0 & 8 & 0 & 0 \\
$181-200$ & 0 & 0 & 3 & 0 & 0 \\
\hline Total & $\mathbf{1 2}$ & $\mathbf{2 7}$ & $\mathbf{3 5}$ & $\mathbf{3 4}$ & $\mathbf{1 2}$ \\
\hline
\end{tabular}

\section{HASIL DAN BAHASAN}

Dari pengamatan terhadap 120 contoh induk ikan lele betina diperoleh data yang menggambarkan distribusi kandungan vitamin $\mathrm{C}$ ovarium pada berbagai tingkat kematangan gonad (TKG) seperti tertera pada Tabel 1.
Kandungan vitamin $\mathrm{C}$ ovarium kelompok TKG I umumnya $(66,66 \%)$ berada pada kisaran $60-100 \mu \mathrm{g} / \mathrm{g}$ dan rata-rata $74,33 \mu \mathrm{g} / \mathrm{g}$, pada kelompok TKG II sebanyak $81,84 \%$ contoh berkisar $101-140 \mu \mathrm{g} / \mathrm{g}$ dan rata-rata $125.72 \mu \mathrm{g} / \mathrm{g}$, dari kelompok TKG III sebanyak $94,00 \%$ berkisar 101$180 \mu \mathrm{g} / \mathrm{g}$, dan rata-rata $155,98 \mu \mathrm{g} / \mathrm{g}$, dari kelompok TKG IV sebanyak $94,00 \%$ berkisar $81-160 \mu \mathrm{g} / \mathrm{g}$ dan rata-rata $127,57 \mu \mathrm{g} / \mathrm{g}$, dan dari kelompok TKG V sebanyak 91,20\% berkisar $81-140 \mu \mathrm{g} / \mathrm{g}$ dengan rata-rata $112,00 \mu \mathrm{g} / \mathrm{g}$. Dari data pada Tabel 1 terlihat bahwa ada fluktuasi kadar vitamin $C$ pada ovarium saat siklus reproduksi. Kandungan vitamin $\mathrm{C}$ ovarium cenderung meningkat sejak awal dan mencapai maksimum pada TKG III, kemudian menurun sampai TKG V. Pola akumulasi vitamin C pada ovarium ikan lele saat siklus reproduksi sama dengan pola yang dijumpai pada spesies ikan trout (Onchorhyncus mykiss) (Sandnes, 1984), ikan Cod (Gadus morrua) (Sandnes and Braekkan, 1981), dan ikan carp (Carassius carassius) (Saeymour, 1981). Dengan mengamati ovarium ikan trout tangkapan di alam, Sandnes (1984) mencatat bahwa kadar vitamin C ovarium pada musim reproduksi berkisar antara $143-379 \mu \mathrm{g} / \mathrm{g}$ dan kadar tertinggi pada masa vitelogenesis. Sandnes and Braekkan (1981) mencatat pula adanya kenaikan kadar vitamin C ovarium ikan cod dari $150 \mu \mathrm{g} / \mathrm{g}$ pada awal menjadi $450 \mu \mathrm{g} / \mathrm{g}$ bobot ovarium basah pada saat perkembangan ovarium, kemudian menjelang pemijahan kandungan vitamin $\mathrm{C}$ menurun mencapai $100 \mu \mathrm{g} / \mathrm{g}$ bobot ovarium basah.

Berdasarkan kandungan vitamin C ovarium dan tingkat kematangan gonad (TKG) ikan lele yang diamati terlihat bahwa terjadi perubahan kandungan vitamin $\mathrm{C}$ ovarium sejalan dengan perkembangan oosit dalam ovarium. Sejak TKG I hingga TKG III kandungan vitamin $C$ memperlihatkan pola meningkat. Pada TKG I seluruh oosit berada pada stadium 1 (awal), kemudian pada TKG II sebagian oosit berkembang mencapai oosit stadium 2 (stadium previtelogenesis) sebanyak 25,48\% dan masih ditemui oosit stadium 1 sebanyak $74,52 \%$. Pada TKG III sebagian besar oosit ditemui pada stadium previtelogenesis sebanyak $35,41 \%$ dan stadium viteloge- 
nesis sebanyak $33,46 \%$ dan pada TKG IV sebagian besar oosit terkelompok dalam dalam oosit stadium 4 (stadium matang) sebanyak $60,64 \%$. Sedangkan pada TKG V komposisi oosit pada ovarium di dominan oleh oosit stadium 1 dan 2, sedikit ditemui oosit stadium 3 dan tidak detemui sama sekali oosit stadium 4 (Tabel 2). Terjadi perubahan struktur komposisi oosit pada ovarium ini sejalan dengan perubahan kandungan vitamin $C$ ovarium. Setelah TKG IV terlihat penurunan yang nyata kandungan vitamin $C$ ovarium sejalan dengan meningkatnya komposisi oosit matang. Ini memperkuat dugaan bahwa pada fase tersebut terjadi penggunaan vitamin $C$ ovarium yang cukup tinggi. Hasil penelitian Agrawal and Mahajan (1980) pada ikan India carp (Labeo rohita, Catla catla dan Cirrhina mrigala) yang tertangkap di alam mencatat bahwa kandungan vitamin $\mathrm{C}$ plasma darah meningkat pada masa perkembangan ovarium dan mencapai minimal pada masa setelah memijah. Sinjal (2007) dalam penelitiannya pada ikan lele (Clarias gariepinus) menghasilkan perlakuan terbaik adalah $1200 \mathrm{mg} / \mathrm{kg}$ vitamin C yang ditambahkan pada makanan kandungan vitamin $C$ pada telur pada awal percobaan adalah $84,64 \mu \mathrm{g} / \mathrm{g}$ dan meningkat pada hari ke 42 adalah $352,72 \mu \mathrm{g} / \mathrm{g}$ dan menurun pada akhir percobaan adalah $306,42 \mu \mathrm{g} / \mathrm{g}$.

Adanya peranan vitamin $\mathrm{C}$ dalam perkembangan oosit diperlihatkan pula dari percobaan Saeymour (1981) yang memperlihatkan bahwa kandungan vitamin C ovarium induk ikan Carassius carassius setelah disuntik dengan kelenjar hipofisis ikan mas lebih rendah dibandingkan dengan induk kontrol yang tidak disuntik. Kandungan vitamin $\mathrm{C}$ ovarium induk yang disuntik dengan hipofisis ikan mas adalah $65,9 \mu \mathrm{g} / \mathrm{g}$ induk kontrol mencapai $121,4 \mu \mathrm{g} / \mathrm{g}$, ukuran diameter oosit dari induk yang menerima perlakuan penyuntikan hipofisis adalah $958 \mu \mathrm{m}$, dan oosit induk kontrol adalah sebesar $899 \mu \mathrm{m}$. Percobaan Akiyama, et. al. (1990) terhadap ikan sardin (Sardinops saxmelanostic) memperlihatkan bahwa ada penurunan vitamin $\mathrm{C}$ ovarium setelah ikan menerima suntikan LHRH. Percobaan Ishibashi, et. al. (1994) pada ikan Oplegnatus fasciatus, spesies ikan yang memijah musiman menunjukkan bahwa tidak ditemui oosit yang mencapai stadium 3 pada ovarium induk yang diberi pakan tanpa supplementasi vitamin $\mathrm{C}$, sedangkan pada induk yang diberi pakan cukup vitamin $C$ banyak ditemui oosit yang mencapai stadium 3 dan oosit stadium 4 (oosit matang) setelah induk dipelihara selama 8 bulan.

Djojosoebagio (1990) mengemukakan bahwa dalam biosintesis hormon steroid reproduksi terjadi beberapa tahapan reaksi hidroksilasi. Vitamin $\mathrm{C}$ berperanan dalam reaksi hidroksilasi biosintesis hormon steroid (Homing, et. al., 1984). Pendapat ini didukung oleh hasil pengamatan Halver dalam Waagbo, et. al., (1984) yang mencatat bahwa vitamin $\mathrm{C}$ diakumulasikan pada sel folikel yang mengitari sel telur. Pada jaringan ini terdapat sel teka yang berperanan dalam sintesis hormon steroid reproduksi (Zohar, 1991). Hasil penelitian Waagbo, et. al., (1989) mencatat pula bahwa vitelogenin plasma dari induk ikan trout (Onchorhynchus mykiss) yang menerima pakan tanpa suplementasi vitamin $C$ sangat rendah dibandingkan induk yang menerima pakan cukup vitamin C pada musim reproduksi. Dengan demikian ketersediaan vitamin C pada ovarium ikan lele berkaitan dengan proses vitelogenesis, karena pada fase ini terjadi proses akumulasi material telur yang menyebabkan perubahan ukuran dan stadium oosit.

Tabel 2. Kisaran dan rata-rata kandungan vitamin $\mathrm{C}$ ( $\mu \mathrm{g} / \mathrm{g}$ bobot basah), dan distribusi oosit pada setiap tingkat kematangan gonad

\begin{tabular}{clrrrrr}
\hline \multirow{2}{*}{$\begin{array}{c}\text { Kematangan } \\
\text { gonad }\end{array}$} & \multicolumn{3}{c}{$\begin{array}{c}\text { Kandungan } \\
\text { vitamin C di }\end{array}$} & \multicolumn{4}{c}{ Distribusi oosit } \\
\cline { 2 - 7 } & \multicolumn{1}{c}{ Kisaran Rata-rata } & \multicolumn{1}{c}{$\mathbf{1}$} & $\mathbf{2}$ & $\mathbf{3}$ & \multicolumn{4}{c}{$\mathbf{4}$} \\
\hline I & $60-100$ & 74.33 & 100.00 & 0.00 & 0.00 & 0.00 \\
II & $101-160$ & 125.72 & 74.52 & 25.48 & 0.00 & 0.00 \\
III & $101-200$ & 155.98 & 28.54 & 28.54 & 33.46 & 2.79 \\
IV & $81-160$ & 127.57 & 15.51 & 15.51 & 8.60 & 60.64 \\
V & $81-140$ & 108.25 & 45.66 & 45.66 & 6.68 & 0.00 \\
\hline
\end{tabular}

Cardinal and Underfriend dalam Soliman et. al. (1986) mengemukakan pendapat lain bahwa tingginya kandungan vitamin $C$ saat ovarium berkembang berkaitan dengan fungsinya sebagai kofaktor enzim prolin dan lisin hidroksilase yang mengkatalisis hidroksilasi dari prolin, lisin dan essensial untuk perkembangan normal jaringan kolagen. Pada penelitian ini tidak dilakukan evaluasi terhadap jaringan kola- 
gen ovarium ikan lele. Namun menurut Sandnes et. al. (1984), kolagen merupakan penyusun utama dinding dalam kantung ovarium. Halver dalam Waagbo et. al. (1989) tidak mengamati adanya akumulasi vitamin $\mathrm{C}$ di jaringan kolagen yang mengitari sel telur, sehingga disimpulkan pula bahwa pada saat ovarium berkembang vitamin $\mathrm{C}$ digunakan untuk sintesis kolagen.

Soliman et. al. (1986) mengemukakan bahwa vitamin $\mathrm{C}$ dalam ransum yang diterima oleh induk dapat ditransfer ke telur dan disiapkan untuk perkembangan embrio, serta sangat mempengaruhi kualitas telur. Pengamatannya pada ikan Oreochromis mossambicus dari induk yang diberi pakan tanpa vitamin C memperlihatkan bahwa kandungan vitamin $C$ telurnya tidak terdeteksi dan daya tetas telurnya lebih rendah dari telur yang diproduksi oleh induk yang menerima pakan cukup vitamin C. Sandnes (1984) telah mengamati kandungan vitamin C telur dari 2 pembenihan ikan Salmon di Norwegia, pertama dari kelompok pembenihan yang memiliki derajat penetasan telur yang tinggi dan kedua kelompok yang selalu menghasilkan derajat penetasan telur yang rendah dan diketahui bahwa kandungan vitamin $\mathrm{C}$ telur dari kelompok pertama adalah $65 \mu \mathrm{g} / \mathrm{g}$ dan dari kelompok kedua adalah $5 \mu \mathrm{g} / \mathrm{g}$. Pengamatan lanjut memperlihatkan bahwa induk yang menerima pakan dengan suplementasi vitamin C $1.000 \mathrm{mg} / \mathrm{kg}$ pakan, kandungan vitamin $\mathrm{C}$ telur mencapai $31 \mu \mathrm{g} / \mathrm{g}$ dan derajat penetasan telur $87 \%$, sedangkan telur dari induk yang menerima pakan tanpa vitamin $\mathrm{C}$, kandungan vitamin $C$ telur $5 \mu \mathrm{g} / \mathrm{g}$ dan derajat penetasan mencapai 25\%. Hasil penelitian Dabrowski and Bloom (1994) mencatat bahwa 37\% cadangan vitamin $\mathrm{C}$ telur digunakan selama perkembangan embrio ikan trout. Ini memperlihatkan pula adanya peningkatan vitamin $C$ ovarium pada masa siklus reproduksi berkaitan dengan akumulasi senyawa tersebut pada telur yang akan dimanfaatkan pada saat perkembangan embrio dan larva.

\section{KESIMPULAN DAN SARAN}

Berdasarkan hasil penelitian kandungan vitamin $\mathrm{C}$ ovarium ikan lele saat siklus reproduksi dapat disimpulkan hal-hal sebagai berikut:

- Kandungan vitamin C ovarium berfluktuasi saat siklus reproduksi dan mencapai maksimum pada TKG III, kemudian menurun hingga TKG $\mathrm{V}$. Peningkatan kandungan vitamin $\mathrm{C}$ ini berkaitan dengan peningkatan stadium oosit; dan

- Vitamin C sangat dibutuhkan pada saat siklus reproduksi dan sebaiknya dijadikan salah satu aspek penting yang harus diperhatikan dalam formulasi pakan induk ikan lele.

\section{DAFTAR PUSTAKA}

Agrawal N. K., \& C. L. Mahajan. 1980. Comparative tissue ascorbic acid studies in fish. J. Fish. Biol., 17:135-141.

Akiyama, T., M. Shiraishi, T. Yamamoto, and K. Hirose. 1990. Variation of administered ascorbic acid levels during maturation and spawning periode in Sardine. Jap. Soc. of fisheries Meeting, October, Abs:436.

Chinabut, S., C. Limsuwan, and P. Kitsawat. 1991. Histology of the walking catfish, Clarias batrachus. IDRC. 93 pp.

Dabrowski, K. and J. H. Bloom. 1994. Ascorbic acid deposition in rainbow trout (Oncorhynchus mykiss) eggs and survival of embryos. Comp. Biochem. Physiol. 109A (1):129-135.

Djojosoebagio, S. 1990. Fisiologi Kelenjar Endokrin II. PALI IPB dan Dept. P dan K. $253 \mathrm{pp}$.

Hengky Sinjal. 2007. Pengaruh Ascorbyl Phosphate Magnesium terhadap kualitas telur Ikan Lele (Clarias gariepinus) (Jurnal Perikanan dan Kelautan vol. III (1) TH. 2007, Hal. 66-74)

Horning D.B., G.G. Glathaar, and U. Mosser. 1984. General aspect of ascorbic acid function and metabolism. Proc. Ascorbic Acid in Domestic Animal. The Royal Danish Agricultural Soc. Copenhagen, p 3-24.

Ishibashi, Y., K. Kato, and S. Ikeda. 1994. Effect of dietary ascorbic acid supplementaqtion on gonadal maturation in Japanese parrot fish. Suisanzoshoku. 42(2):279-285.

Lutwak-Mann, C. (1958). The dependence of gonadal function upon vitamin and other 
nultritional factors. Vitamin Hormon. 16:3557.

Saeymour, E.A., 1981. Gonadal ascorbic acid and changes in lebel with ovarian development in the crussian carp (Carassius carassius). Comp. Bioche. Physiol. 70A:551-553.

Sandnes, K. 1981. Some aspects of ascorbic acid on reproduction in fish. Proc. Ascorbic Acid in Domestic Animals. The Royal Danish Agricultural Soc. Copenhagen. p:206-212.

Sandnes, K., Y. Ulgenes, O. R. Braekkan, and F. Utne. 1984. The effect of ascorbic acid supplementation in broodstock feed on reproduction of rainbowtrout (Oncorhynchus mykiss). Aquaculture. 43:167-177.

Sandnes, K., and Braekkan. 1981. Ascorbic acid and reproductive cycle of ovaries in Cod (Gadus morrhua). Comp. Biochem. Physiol. 70:543-546.
Schuep, W., P. Hoffman, and E. Kock. 1994. The assay of ascorbic acid in tissue and the analysis of ascor-bate-2-polyphosphate in feed and its stability. Roche Seminar, Jakarta. p:1-6.

Soliman, A. K., K. Jauncey, and R.J. Robert. 1986. The effect of dietary ascorbic acid supplementation on hatchability, survival rate and fry performance in Oreochromis mossambicus. Aquaculture. 59:197-208.

Waagboo, R., T. Thorson, and K. Sandnes. 1989. Role of dietary ascorbic acid in vitelogenesis in rainbow trout. Aquaculture, 80:301-314.

Zohar, Y. 1991. Fish reproduction: Its physiology and artificial manipulation. In S. Shilo and S. Sarig (Eds.). Fish Culture in Warm Water Problems and Trends. GRC Press. p:65-119. 